\title{
What Works for Underrepresented \\ Groups? Identifying Effective Measures \\ for Enhancing Access to Higher \\ Education in Europe
}

\author{
Simona Torotcoi, Delia Gologan, and Anastasia Kurysheva
}

\section{Equity Considerations Within the Bologna Process}

Despite the general increasing access to tertiary education, HE systems remain highly stratified (Marginson 2016), gender imbalances still exist between different fields of study, and students with an immigrant background or with parents without a HE degree have lower chances to achieve tertiary attainment, etc. (European Commission/EACEA/Eurydice 2018). On the one hand, there is a social demand for access to a variety of degrees (i.e., high-status professional degrees, or within elite universities), on the other, there is a normative inquiry for access to quality education for a diversity of students. Widening access and participation can be regarded as a strategy for change since the social benefits of inclusion in HE can have long term effects both for the individual and the society he/she lives in. Among these there are: tolerance and expanded social networks, contribution to the economy, cohesiveness in society, political participation, health and wellbeing, lower crime propensity, higher earning potential, better parenting and others (Murray 2009).

\footnotetext{
S. Torotcoi $(\bowtie)$

Central European University, Budapest, Hungary

e-mail: torotcoi_simona@phd.ceu.edu

D. Gologan

University of Bucharest, Bucharest, Romania

e-mail: delia.gologan@gmail.com
}
A. Kurysheva
Utrecht University and University Medical Center Utrecht, Utrecht, The Netherlands
e-mail: a.kurysheva@umcutrecht.nl 


\subsection{Access to Higher Education as Part of General Equity Discourses}

In HE policy the concept of equity-originated in welfare economics-started to be used at different moments in time, in different places around the world, usually along with the shift from elitist universities towards mass HE systems. There is no one single definition of equity in HE policy, but several that are more prominent both in the literature and among practitioners, thus showing the flexibility of the concept and the divergent understandings of it by both researchers and policy-makers. It is understood as equality, providing equal opportunities for access to and success in $\mathrm{HE}$ in order to even out the circumstances that are beyond one's control (i.e., financial resources of the family or educational attainment of the parents) (Salmi and Bassett 2014). The concept is linked to evening out (previous or existing) inequalities through the special allocation of resources that could be translated into HE policies, and policy instruments (Geven 2012).

Equity is sometimes considered to be synonymous with access to HE thus with "widening participation and improving the chances of success of under-privileged youths" (Salmi and Bassett 2014) through utilizing tools for ensuring diversity (i.e., affirmative action).

In its narrow sense, access to HE can be defined as entry/admission to HE (Prodan et al. 2015) while more generally, it can be defined as the ability of people from all backgrounds to access HE on a reasonably equal basis (Usher and Medow 2010; Wang 2011). This definition is comprehensive in scope and implies that students of all backgrounds must not only be "reasonably" able to take advantage of educational opportunities, but also must be adequately prepared and equipped to do so in order for the system to be considered "accessible". In both cases, it is merely the starting point whereas the final goal of access policies is successful participation (Tonks and Farr 2003).

Considering this, interventions aimed at HE equity address one or a combination of access, retention and persistence and successful transition to further studies or professional career. Holistic approaches tackle all potential sources of inequity such as socio-economic, ethnic, gender- and disability-based, both at individual and systemlevel through policy instruments that equalize economic, cultural and social capital within the education system (Geven 2012). These approaches can propose solutions for the difficulties encountered by students enrolled in lower levels of education (primary or secondary), at the transition between secondary and HE, or while attempting to enrol, participate in and successfully graduate from HE programs. These types of holistic approaches to inequities are needed as barriers tend to overlap in the cases of potential students coming from difficult socio-economic backgrounds that are traditionally underrepresented in the educational system or are excluded from it. However, there is no one-size-fits-all type of solution (no mix of policies will work everywhere), and initiatives in the field should address the goal of eliminating both individual and system barriers (e.g. admission selection should be freed of any privilege bias) (Usher 2015). 


\subsection{The Social Dimension of the Bologna Process}

The Bologna Process (and the subsequent European Higher Education AreaEHEA) represents the most significant and ambitious HE agenda in Europe with an equity dimension. The Sorbonne Declaration referred to the fact that "students should be able to enter the academic world at any time in their professional life and from diverse backgrounds" (1998, 2), and this was the beginning of the sequence of moments linked to the Bologna Process when countries reiterated their support for integrating a diverse student body within their programs and structures. Therefore, in 2001, through the Prague Communiqué, member states were encouraged to create lifelong learning policies, to facilitate the partnership of HEIs and students in promoting the attractiveness of the EHEA, as well as the policies aiming at the social dimension of HE, including the access of underrepresented groups. The 2003 Berlin Communiqué acknowledged that "the need to increase competitiveness must be balanced with the objective of improving the social characteristics of the EHEA, aiming at strengthening social cohesion and reducing social and gender inequalities both at national and at European level". This trend continued in the ministerial conferences after 2003, as it became clear that the social dimension includes measures taken by governments "to help students, especially from socially disadvantaged groups, in financial and economic aspects and to provide them with guidance and counselling services with a view to widening access" (Bergen Communiqué 2005). As of 2007, participating countries were asked to report on the actions taken at the national-level and on the effectiveness of national action plans and measures targeting the social dimension of HE (i.e. access participation and completion measures for underrepresented students). More specifically, some of the means refer to adequate student support and services, counselling and guidance, flexible learning paths and alternative access routes, including recognition of prior learning (Bucharest Communiqué 2012), but also implementing the EHEA social dimension strategy (Yerevan Communiqué 2015). However, the social dimension of the Bologna Process remains one policy action with very few concrete results.

\subsection{Literature Gap and Methodology}

A significant number of countries and HEIs have started investing resources and take onboard initiatives aiming at widening access for disadvantaged or underrepresented groups - that we will refer to from now on as "equity groups"-(i.e., through quota systems, preparatory programs, etc.). However, little is known about whether such initiatives actually shape opportunities for potential students. Knowing which of these initiatives work and whether they are achieving the intended goals is of utmost importance for policy-makers. Given the fact that national-level programs might provide different responses/reactions from HEIs, which have a certain level of 
autonomy, this paper addresses the relative effectiveness of access initiatives at the HEIs level.

While in the US there is a considerable amount of research about the effectiveness of access policies (Pharris-Ciurej et al. 2012; Perna et al. 2008; Myers et al. 2010), in Europe we found very few such studies focusing on the university level, fact which motivated us to take up the challenge of mapping them out. The existing literature focusing on Europe are systematic reviews of evidence on the effectiveness of interventions for widening access, participation and completion rates of equity groups in HE. For example, Torgerson et al. (2014) and Younger et al. (2019) provide a synthesis of the international evidence, mainly from the US and the UK. Similarly, Herbaut and Geven (2019) selected 71 studies, most of them across the US and few from Europe, and compared more than 200 causal effects of outreach and financial aid interventions on access and completion.

As Perna et al. (2008) claim, efforts to understand why policies and programs are not working are hampered by the absence of a framework for organizing the myriad efforts designed to reduce participation gaps and, by extension, for demonstrating policy blind spots and redundancies. The overarching aim of this paper is to contribute in addressing the current literature gap by focusing specifically on access measures and interventions for widening access for equity groups, that can be primarily addressed on HEIs level. ${ }^{1}$ For this purpose, the paper will collect, document, scrutinize and critically analyze the current research literature (i.e., through the work of others, evaluation reports/studies, etc.) which assesses the effectiveness of these types of policies, aiming, at the same time, to identify gaps and make recommendations for both potential further research and for policy-makers. The main research question this paper explores is: what is the relative effectiveness of different access measures implemented at the university level, and which characteristics moderate their effectiveness?

Before proceeding to the actual research, it is worth mentioning what is referred to here as access, who are the equity groups and how effectiveness and impact can be measured. For the purpose of this paper, access is defined here in a narrow sense as entry/admission to and enrolment of students in HE education programs (Prodan et al. 2015). As far as the underrepresented groups are concerned, authors chose to refer to a broad category of students, including those with diverse, ethnic, cultural and migration background, sexual identity and orientation, socio-economic background, educational background (alternative pathways, lifelong learners, first-generation students), caring responsibilities, religious background/beliefs, age or students from rural areas (c.f. Claeys-Kulik et al. 2019). When it comes to the effectiveness of various approaches to increase access to $\mathrm{HE}$, the authors opted to consider the extent to which (i.e.) a program has reached the goal(s) that has been set initially, or whether it achieves the set expectations or the goal(s) that were intended or desired by stakeholders. Similarly, Cowan (1985) refers to effectiveness as the ratio of the actual

\footnotetext{
${ }^{1}$ It is part of a larger effort and preoccupation of the authors to address all types of measures and interventions targeting reducing inequities, but this paper only presents the results connected to different types of access measures.
} 
outcome to the possible or the ideal outcome. The three most often used indicators for measuring the impact of HEIs activities on diversity, equity and inclusion refer to the number/share of students enrolled from less represented/disadvantaged backgrounds, the success stories of the people targeted through the measures, and the graduation rate of students from underrepresented/disadvantaged backgrounds (Claeys-Kulik et al. 2019). For the purpose of this paper, we will be looking at the first set of indicators but keeping in mind the initial goals and intentions of the measure under consideration.

In order to reach the expected results, we first undergo a mapping exercise looking for studies referring to the access policies relevant to our research initiative. The approach for this entailed extensive searches of comprehensive education databases such as Web of Science and the Educational Resources Information Center (ERIC) the world's largest educational database and the most frequently used index for carrying out educational research. The search for the studies of interest was also conducted through the Google Scholar search engine using combinations of search words referring both to the interventions of interest (e.g. bridging programme) and to underrepresented groups of students (e.g. first-generation students). The search was complemented by consulting the bibliography/reference list of related studies, by consulting the (non-academic) publications of key organizations and structures in the HE sector in Europe, and by our knowledge on studies on the topic including non-academic studies from different organizations, structures and HEIs. In line with similar studies (Younger et al. 2019), publications' titles and abstracts in these databases were searched for a combination of keywords related to "underrepresented groups" in/or/and "higher education", "tertiary education" or "universities". In total, a number of 17 studies written in English have been included in the sample used for this paper, out of which two of them are non-academic. The selection was first and foremost determined by the availability of studies analyzing institutional-level equity policies.

Section 2 of this paper looks at the different social dimension targets set by the EHEA participating countries and evaluates policy instruments (financial and nonfinancial) promoting equity.

\section{Access Policies Between National Frameworks and Institutional Practices}

In Europe, the social dimension is an increasingly important policy issue with both state and HEIs intervening to increase access and participation. The 2018 Bologna Implementation Report states that several countries have set long-term goals and targets with regards to the access of different social groups. For example, by 2025 , Austria aims to have at least $10 \%$ of men/women in each study program and increase the proportion of second-generation immigrants among entrants to $30 \%$. By 2030 , Scotland aims to increase the access for students coming from the most deprived 
backgrounds so that it represents $20 \%$ of the entrants. By 2020, the Czech Republic set out to increase the access of students with specific educational needs in HE so that their share will be close to share among high school graduates. Setting such targets is a crucial step, however, considering the fact that the admission systems provide the transition to HE, they are the key point for determining which students go into which type of HEI (Haj et al. 2018). The type of admission systems in a country can positively contribute or hamper equity and access. Orr et al. (2017) and Haj et al. (2018) reflected on the types of admission systems and their impact on the equity of access, progression and completion in HE in Europe. By using 36 European countries, Orr et al. (2017) created a two-dimensional typology of admission systems based on the extent to which school streaming leads to some forms of HE, and whether HEIs have the autonomy to use their own selection criteria.

The result of Orr et al. (2017) typology is a four type admission system as follows: a selection by schools system (Type 1) in which secondary schooling does not lead to HE entry, and HEIs cannot select with additional criteria; a selection by HEIs (Type 2) in which HEIs can select with additional criteria, and all previous schooling pathways may lead to HE entry; a least selection system in which neither the school system limits students nor the HEIs select them (Type 3); and the last type, a double selection in which both the school system and HEIs select students (Type 4). An assessment of the performance of each type (Orr et al. 2017) shows that HE entry rates are higher where HEIs have increased autonomy. Moreover, countries that put up the fewest academic barriers to access to $\mathrm{HE}$ are also the ones with the most equitable outcomes by social background (measured using HE attainment of graduates' parents), whereas countries in which HEIs can use their own admission criteria are more likely to admit a higher proportion of mature students. In countries with streams not leading to HE, and HEIs have the autonomy in organizing assessment, females have a higher increase in participation between upper-secondary and HE.

When it comes about these types' performance with regards to equity Haj et al. (2018) argue that the systems with the selection system Type 1 have the lowest relative participation rates of students from low socio-economic backgrounds. This is due, on the one hand, to the school streaming where pupils are placed in schools with different likelihoods of leading to HE, on the other hand, by HEIs using students' secondary school examination scores for admission. In Type 2 systems equity is not restricted as in Type 1. However, when applying additional criteria, HEIs might focus on the academic achievement of the student, limiting the chances for students with lower socio-economic backgrounds, contributing therefore to perpetuating inequality. Provided the level of autonomy HEIs have, they can promote their own discretion positive actions for certain groups of students, or alternatively can control the student distribution per field of study (Haj et al. 2018). Type 3 systems present the best outcome in terms of equity since it has the fewest barriers to access, but compared to systems in which HEIs can select students, these Type 3 systems might have higher drop-out rates since HEIs might not be able to get students that fit with a study program (Haj et al. 2018). Last but not least, Type 4 systems are expected to be the least equitable considering both the school streaming and HEIs selection criteria, with numerous potential students that are not being considered for HE (Haj et al. 2018). 


\section{Access Measures and Their Effects: What Works for Underrepresented Groups?}

Access measures can be categorized in several ways: whether they are financial or non-financial, the problem they tackle, the phase they intervene in (i.e., during secondary education, during the transition to $\mathrm{HE}$ or after the enrolment in the $\mathrm{HE}$ system).

As far as financial instruments are concerned, they might primarily target students with low socio-economic backgrounds, but might target other equity groups as well. However, it is widely known that the principal dimensions of inequality overlap in many ways, for example, ethnic minorities are more likely to live in rural areas or peripheral neighbourhoods and, therefore, are more likely to be affected by poverty. Salmi (2018) argues that, nowadays, financial aid policies are the most commonly used, often in combination with non-monetary aid policies. Among these is worth mentioning the tuition-free or partially subsidized HE, the needs-based grants, scholarships and bursaries, student loans, and a variety of funding formulas.

As far as the non-financial policy instruments are concerned, the most widespread practices relate to different forms of positive discrimination, reformed selection procedures and/or preferential admission programs. For example, Usher (2015) identifies several categories of measures universities can incorporate within their work aimed at enhancing $\mathrm{HE}$, including early interventions strategies designed to eliminate barriers in the educational pipeline prior to tertiary education. Claeys-Kulik et al. (2019) put forward 12 most frequently used access measures used by universities among which: guidance, counselling and mentoring, accessible building and activities, assurance about non-discrimination, part-time study options and flexible courses, financial support, preparatory courses, recognition of prior learning, childcare on campus, positive action, housing support, quotas for students from certain groups/backgrounds, and general positive discrimination measures.

As resulted from our bibliographic search, most of the identified studies focus on three main measures as summarized in Table 1. It provides an overview of the identified studies as follows: blue-outreach, counselling and mentoring; yellowfinancial aid; green — preparatory courses and programs. It also summarizes the main aim of the study, its data and method, and the main finding with regards to effectiveness ("+"- effective, "-"-negative, or "0"- -no effects).

As Table 1 above shows, with some exceptions (i.e., the studies focusing on Aimhigher) the identified studies look at different measures targeting different equity groups of students, in different countries and HEIs contexts, and, therefore, the findings do not allow for a cross-comparison of the results. Thus, we abstain from making obsolete conclusions and cause-effect inferences. Rather, the conclusions we reached represent the authors' opinions as emerged from the analysis of the studies sample of the paper. The section below (1) provides a general description of the type of measures under consideration, (2) offers several examples of such measures by specifying the university accommodating the measure, the type of measure and its components, its target group and the intended goals of that specific measure, and 
Table 1 Overview of the identified studies

\begin{tabular}{|c|c|c|c|}
\hline Author(s) and measure & Aim of the study & Data and method & Effects \\
\hline $\begin{array}{l}\text { Gumaelius et al. (2016) } \\
\text { Outreach }\end{array}$ & $\begin{array}{l}\text { To describe and compare } \\
\text { outreach initiatives aimed } \\
\text { at increasing enrolment in } \\
\text { engineering programs } \\
\text { (DE, DK, SE, ES, PT) }\end{array}$ & $\begin{array}{l}\text { Self-reported institutional } \\
\text { data; comparative analysis }\end{array}$ & + \\
\hline $\begin{array}{l}\text { Pekkala-Kerr et al. (2015) } \\
\text { Information }\end{array}$ & $\begin{array}{l}\text { To test whether the match } \\
\text { between educational } \\
\text { choices and the demand } \\
\text { for skills in the labour } \\
\text { market can be enhanced } \\
\text { by providing information } \\
\text { (FIN) }\end{array}$ & $\begin{array}{l}\text { Randomized field } \\
\text { experiment with } \\
\text { graduating high-school } \\
\text { students }\end{array}$ & 0 \\
\hline $\begin{array}{l}\text { Ehlert et al. (2017) } \\
\text { General information }\end{array}$ & $\begin{array}{l}\text { To examine whether } \\
\text { correct and detailed } \\
\text { information on the costs of } \\
\text { and returns to HE } \\
\text { increases the likelihood of } \\
\text { HE applications (DE) }\end{array}$ & $\begin{array}{l}\text { Field experiment with } \\
\text { less-privileged high school } \\
\text { graduates }\end{array}$ & + \\
\hline $\begin{array}{l}\text { Abbiati et al. (2018) } \\
\text { Personalized information }\end{array}$ & $\begin{array}{l}\text { To assess the role of } \\
\text { information barriers for } \\
\text { patterns of participation in } \\
\text { HE and the related social } \\
\text { inequalities (IT) }\end{array}$ & $\begin{array}{l}\text { Randomized experiment } \\
\text { with high school seniors }\end{array}$ & + \\
\hline $\begin{array}{l}\text { Wulz et al. (2018) } \\
\text { Counselling }\end{array}$ & $\begin{array}{l}\text { To provide an overview of } \\
\text { counselling activities } \\
\text { targeting disadvantaged } \\
\text { learners (AT, DE, ES, IT, } \\
\text { LI, UK, RO, DK, SL) }\end{array}$ & $\begin{array}{l}\text { Survey with national } \\
\text { student unions }\end{array}$ & + \\
\hline $\begin{array}{l}\text { Doyle and Griffin (2012) } \\
\text { Mentoring }\end{array}$ & $\begin{array}{l}\text { To review Aimhigher's } \\
\text { contribution to widening } \\
\text { participation for students } \\
\text { with non-traditional } \\
\text { backgrounds (UK) }\end{array}$ & Literature review & + \\
\hline $\begin{array}{l}\text { McCaig and } \\
\text { Bowers-Brown (2007) } \\
\text { Mentoring }\end{array}$ & $\begin{array}{l}\text { To determine the success } \\
\text { of Aimhigher as a } \\
\text { potential mechanism of } \\
\text { social justice (UK) }\end{array}$ & Literature review & - \\
\hline $\begin{array}{l}\text { Fack and Grenet (2015) } \\
\text { Fee-waiver }\end{array}$ & $\begin{array}{l}\text { To provide evidence on } \\
\text { the impact of a need-based } \\
\text { grant on HE enrolment for } \\
\text { low-income students (FR) }\end{array}$ & $\begin{array}{l}\text { Regression discontinuity } \\
\text { design }\end{array}$ & + \\
\hline $\begin{array}{l}\text { Baumgartner and Steiner } \\
\text { (2006) Financial aid }\end{array}$ & $\begin{array}{l}\text { To evaluate the } \\
\text { effectiveness of student } \\
\text { aid targeting students from } \\
\text { low-income families (DE) }\end{array}$ & Difference-in-difference & $+/-$ \\
\hline
\end{tabular}


Table 1 (continued)

\begin{tabular}{|c|c|c|c|}
\hline Author(s) and measure & Aim of the study & Data and method & Effects \\
\hline Hatt et al. (2005) Bursaries & $\begin{array}{l}\text { To explore how HEIs } \\
\text { administered a } \\
\text { national-level bursary } \\
\text { scheme (UK) }\end{array}$ & $\begin{array}{l}\text { Institutional databases and } \\
\text { interviews with bursary } \\
\text { students }\end{array}$ & + \\
\hline $\begin{array}{l}\text { Lannert and Garaz (2014) } \\
\text { Scholarship }\end{array}$ & $\begin{array}{l}\text { To investigate the degree } \\
\text { in which the scholarship } \\
\text { contributed to enhance } \\
\text { access }\end{array}$ & $\begin{array}{l}\text { Online survey, focus } \\
\text { groups and interviews } \\
\text { with beneficiaries }\end{array}$ & + \\
\hline $\begin{array}{l}\text { Roma Education Fund } \\
\text { (2015) Scholarship mix }\end{array}$ & $\begin{array}{l}\text { To investigate whether the } \\
\text { scholarship contributed to } \\
\text { the academic trajectory of } \\
\text { its beneficiaries }\end{array}$ & $\begin{array}{l}\text { Program data, and surveys } \\
\text { with mentors and } \\
\text { beneficiaries }\end{array}$ & + \\
\hline $\begin{array}{l}\text { Berg (2018) Language } \\
\text { classes }\end{array}$ & $\begin{array}{l}\text { To compare the support } \\
\text { and integration programs } \\
\text { at different HEIs (DE) }\end{array}$ & Interviews & + \\
\hline Rostas (2017) Mixed & $\begin{array}{l}\text { To understand the impact } \\
\text { of measures supporting } \\
\text { Roma's access to HE }\end{array}$ & Personal experience & + \\
\hline $\begin{array}{l}\text { Pinheiro-Torres and } \\
\text { Davies (2008) Mixed }\end{array}$ & $\begin{array}{l}\text { To evaluate the } \\
\text { effectiveness of a program } \\
\text { supporting higher ability } \\
\text { students from lower } \\
\text { socio-economic } \\
\text { backgrounds }\end{array}$ & Program data & + \\
\hline Casey et al. (2011) Mixed & $\begin{array}{l}\text { To identify students' } \\
\text { responses to the different } \\
\text { components of the } \\
\text { program }\end{array}$ & $\begin{array}{l}\text { Program data; longitudinal } \\
\text { study }\end{array}$ & + \\
\hline $\begin{array}{l}\text { Walker (2010) } \\
\text { Pre-university summer } \\
\text { school }\end{array}$ & $\begin{array}{l}\text { To assess the impact on } \\
\text { enrolment and retention of } \\
\text { non-traditional students } \\
\text { attending the summer } \\
\text { school }\end{array}$ & Institutional data & $+/-$ \\
\hline
\end{tabular}

(3) synthesizes the evidence collected on their effectiveness and impact based on existing studies.

\subsection{Outreach, Counselling and Mentoring of Prospective Students}

Early interventions for eliminating barriers prior to access to HE include outreach and bridging programs or services like personal and professional counselling, mentoring 
Table 2 Selected examples of outreach, counseling and mentoring of prospective students

\begin{tabular}{l|l|l|l}
\hline HEI & $\begin{array}{l}\text { Type of measure and } \\
\text { components }\end{array}$ & Target group & Intended goal(s) \\
\hline $\begin{array}{l}\text { University of } \\
\text { Barcelona, Spain }\end{array}$ & $\begin{array}{l}\text { Full tuition } \\
\text { scholarship, housing, } \\
\text { free language course, } \\
\text { mentoring, legal } \\
\text { advice, psychological } \\
\text { support and dental care }\end{array}$ & Refugees & $\begin{array}{l}\text { Widen access and } \\
\text { ensure participation }\end{array}$ \\
\hline $\begin{array}{l}\text { University College } \\
\text { Dublin, Ireland }\end{array}$ & $\begin{array}{l}\text { Outreach-Student } \\
\text { access leader } \\
\text { programme }\end{array}$ & $\begin{array}{l}\text { Students with } \\
\text { disabilities, mature } \\
\text { and part-time learners, } \\
\text { and students from } \\
\text { socio-economic } \\
\text { disadvantage }\end{array}$ & $\begin{array}{l}\text { Widen access and } \\
\text { ensure participation }\end{array}$ \\
\hline $\begin{array}{l}\text { University of Lille, } \\
\text { France }\end{array}$ & $\begin{array}{l}\text { Financial and } \\
\text { pedagogical support to } \\
\text { students from } \\
\text { disadvantaged } \\
\text { backgrounds during } \\
\text { their first year of study }\end{array}$ & $\begin{array}{l}\text { Supporting students } \\
\text { from } \\
\text { socio-economically } \\
\text { disadvantaged } \\
\text { backgrounds }\end{array}$ & $\begin{array}{l}\text { Ease access to } \\
\text { graduate and } \\
\text { postgraduate studies }\end{array}$ \\
\hline $\begin{array}{l}\text { University of } \\
\text { Strathclyde, UK }\end{array}$ & $\begin{array}{l}\text { Introduce prospective } \\
\text { students to the life on } \\
\text { campus and deliver } \\
\text { tailored learning } \\
\text { activities }\end{array}$ & Prospective students & $\begin{array}{l}\text { Increase students' } \\
\text { awareness of various } \\
\text { HE aspects (i.e., } \\
\text { courses and entry } \\
\text { requirements) }\end{array}$ \\
\hline
\end{tabular}

and tutoring systems or general academic support. Counselling is applied in a wide range of areas such as education problems, psychological issues, career guidance, and disability guidance and it can be used as a tool for reducing dropout (Wulz et al. 2018). Counselling can be provided by universities, private associations, NGOs, etc. and can support the increase in demand to access HE (Wulz et al. 2018). The counselling of prospective students can serve as a source of social capital for firstgeneration students (Pham and Keenan 2011) helping them to overcome a lack of social capital, assistance and advice from their families. Career counselling and personal development programs can also contribute in improving retention rates and results (outcomes). While in some countries universities have an obligation to provide counselling, in others-especially those with high demands to access HEmany private associations or NGOs provide it. Specific counselling is offered to different equity groups. Table 2 below exemplifies the different measures within this category implemented by universities.

The identified studies focusing on this category of measures show that they have a relatively positive effect on access. However, one should consider that outreach initiatives aimed at increasing interest in science and technology are evaluated either based on whether participants liked the activities or not, or based on changes in the enrolment of a degree program (Gumaelius et al. 2016). For example, the Stockholm 
University summer school and the Praktikum UPV (at Universitat Politècnica de València) provide activities for prospective students closely related to universities' everyday activities, including the opportunity for school students to perform small research projects with Ph.D. students. Praktikum UPV includes a one-week stay for secondary school students within university research groups for fostering engineering and scientific vocations. Both initiatives measured the number of participants who chose to enrol in a STEM program at their university after the activities are completed. At Stockholm University, 12-14\% of them chose to study a STEM field at Stockholm University, and $70 \%$ chose to do so at UPV (however, participants might choose to attend a STEM program at another university, which is not reflected in the percentage but could be considered a success).

Pekkala-Kerr et al. (2015) examined the impact of an information intervention offered by student guidance counsellors to randomly chosen high schools in Finland on the return to HE, including labour market prospects associated with postsecondary programs. The results show that on average, the information intervention did not affect the likelihood of being enrolled in a post-secondary program or the type of programs where students enrolled. Furthermore, the study shows that the application patterns among students graduating from the treatment and control school are indistinguishable from each other, but a third of the students reported that the intervention led them to update their beliefs regarding their return to HE.

In Germany, Ehlert et al. (2017) conducted a field experiment among high-school students from Berlin who had HE intentions to find out whether information deficits lower the likelihood of college-eligible students from less-privileged families to pursue their college intentions. The findings show an increase in the application rates overall, including for students without academic background parents, with one college-educated parent, though no significant effect when both parents have an academic degree.

A large-scale clustered randomized experiment (Abbiati et al. 2018) involving over 9,000 high school seniors from 62 Italian schools shows that overall, treated students (who were provided personalized information on the costs, benefits and chances of success in HE through three meetings) enrolled less often in less remunerative fields of study in favour of postsecondary vocational programs (the latter was mainly due to the offspring of low-educated parents). The study shows that children of $\mathrm{HE}$ graduates increased their participation in more rewarding university fields.

Looking at existing practices and needs in terms of guidance for inclusion in European universities, Cullen (2013) suggests that "institutions that adopt peer and mentoring support programs have lower rates of dropout" (cited in Wulz et al. 2018). More specifically, they are successful in preventing dropouts. Wulz et al. (2018) consider that counselling is an effective measure to widen participation in HE, together with the provision of student facilities (e.g. housing, medical support, childcare). $74 \%$ of the beneficiaries of student union counselling perceived it as useful (study referred to by Wulz et al. 2018).

Looking at the impact of Aimhigher (2004-2011) on widening participation in HE for young people from underrepresented groups (pupils aged 12-16 including first-generation students) in England, Doyle and Griffin (2012) find positive effects 
on pre-entry mentoring (information advice and guidance) on students' aspirationraising and access to $\mathrm{HE}$ when combined with other measures, such as campus visits or guest lectures. However, results of Aimhigher are mixed, with Doyle and Griffin (2012) finding positive effects for mentoring, but McCaig and Bowers-Brown (2007) finding no measurable impact but rather 'smoking gun' causal links between Aimhigher and enrolment.

To conclude, the seven identified studies show that the discussed measures do not have a strong potential by themselves but work best when combined with others. Personal and professional pre-entry counselling, mentoring tutoring systems, and academic support reach maximum results when complemented by a "school culture that values and promotes going into tertiary education, that sets high expectations for participation in higher education and offers a curriculum that attracts and supports students in their postsecondary and career development" (Salmi and Bassett 2014). Moreover, they are considered more efficient in systems that have a clear set pathway towards HE through secondary education (like Anglo-Saxon educational systems), and less in countries like Germany that select students for different streams of the system early in their educational careers (Usher 2015).

\subsection{Financial Aid Measures}

Initiatives addressing the financial barriers that students face aim at easing the financial pressure for students already considered eligible. They are either reimbursable or non-reimbursable. The latter are under the form of needs-based grants and scholarships that target students coming from families with lower income, certain ethnic minority groups or rural areas, women or students with disabilities. The alternative is often tuition fee waivers or subsidies for the traditionally underrepresented groups. All of them aim at eliminating the possibility that the low family income acts as a deterrent to access and success in HE. Reimbursable financial aid schemes (i.e., student loans) are sustainable forms of financial support requiring a lean administration setup, low subsidies and an effective recovery system. They are implemented differing in terms of the source of capital, the type of expenses they cover, the eligibility rules, the guarantees they require, and the repayment scheme (e.g. direct loans; loans guaranteed by the Government that are shared-risk loans; income-contingent loans). Table 3 provides several examples of the shape and dimensions of financial aid measures embraced by several universities.

Existing studies focusing on Europe show that the amount of aid had a direct effect on HE enrolment and access. Fack and Grenet (2015) show that a fee-waiver (which amounted to 174 euros) in France had small positive effects on enrolment in the first year of undergraduate programs, whereas the provision of 1,500 euros cash allowances to prospective undergraduate or graduate students increases their college enrolment rates by $5-7 \%$.

Baumgartner and Steiner (2006) evaluated the effectiveness of a student aid reform in Germany that substantially increased the amount received by eligible students to 
Table 3 Selected examples of financial aid measures

\begin{tabular}{l|l|l|l}
\hline HEI & $\begin{array}{l}\text { Type of measure and } \\
\text { components }\end{array}$ & Target group & Intended goal(s) \\
\hline $\begin{array}{l}\text { Open University of } \\
\text { Catalonia, Spain }\end{array}$ & $\begin{array}{l}\text { Scholarships and } \\
\text { online learning }\end{array}$ & $\begin{array}{l}\text { Professionals, refugees } \\
\text { and asylum-seekers, } \\
\text { people with functional } \\
\text { diversity }\end{array}$ & $\begin{array}{l}\text { Providing flexible } \\
\text { distance learning } \\
\text { degree programs }\end{array}$ \\
\hline $\begin{array}{l}\text { Universities of } \\
\text { Glasgow, York, } \\
\text { Barcelona, Edinburgh, } \\
\text { Sussex, Warwick }\end{array}$ & $\begin{array}{l}\text { Scholarships (i.e., } \\
\text { waiving fees, } \\
\text { providing tuition } \\
\text { scholarships, and } \\
\text { offering free courses) }\end{array}$ & Refugees & $\begin{array}{l}\text { Widen access and } \\
\text { ensure participation }\end{array}$ \\
\hline $\begin{array}{l}\text { University of } \\
\text { Vincennes in }\end{array}$ & $\begin{array}{l}\text { Scholarships for } \\
\text { refugees with little } \\
\text { knownt-Denis, France } \\
\text { French-Diploma } \\
\text { University (DU) }\end{array}$ & Refugees & $\begin{array}{l}\text { Preparation for } \\
\text { additional academic } \\
\text { courses }\end{array}$ \\
\hline
\end{tabular}

raise enrolment rates into tertiary education. The study found that the reform had a small positive, but statistically insignificant, effect on enrolment rates despite the $10 \%$ increase in the federal students' financial assistance scheme.

Hatt et al. (2005) evaluated the Opportunity Bursary scheme (introduced in 2001), for students from low-income backgrounds where institutions were allowed considerable discretion over the allocation of these awards. The research reports differences in the way the two institutions - in the South-west of England — administered their bursary schemes, and the generated effects: bursary students from low-income backgrounds were more likely to continue beyond the year of entry than those students from low-income backgrounds who did not access the award. Moreover, it also revealed that the award of a bursary is strengthening the student's motivation to succeed and playing an active role in underpinning student persistence and success. Hatt et al. (2005) argue that there are two possible explanations for this effect upon HE continuation as the money might be useful and might strengthen the student's commitment to study.

Lannert and Garaz (2014) are tracing Roma Education Fund's (REF) Law and Humanities Program scholarship beneficiaries (awarded a yearly amount between 500-2300 EUR depending on the existence of a tuition fee and living expenses) in Moldova, Russia and Ukraine. Between 2004 and 2014, a total of 413 students benefited from the scholarship scheme. The results of their evaluation show that among these, 200 (48\%) students obtained at least tertiary level degree with complete or partial LHP support, while 144 did not graduate yet but are still in the program. Also, 35 beneficiaries ( $8 \%$ ) dropped out of their university studies before graduation or postponed graduation for later.

Since it was launched, in 2008, and until the summer of 2015, REF's Roma Health Scholarship Program (RHSP) provided support to 527 Roma medical students from 
Romania, North Macedonia, Serbia and Bulgaria. The support can be operationalized as financial, academic and professional (i.e., scholarships-between 375 EUR and 5,360 EUR per academic year, preparatory courses, mentorship, advocacy camps and additional funding for courses, conferences and small community development projects). Out of the 527 beneficiaries, 146 (28\%) were still in the program at the time of the study, 187 people graduated successfully with at least one degree and exited the program, 45 people interrupted their studies or dropped out, and 57 people continued their studies without RHSP support, and 86 people exited the program, but their academic progress and graduation status could not be tracked (Roma Education Fund 2015).

The evaluated evidence shows that the amount of the financial aid can have positive effects on enrolment, but, depending on the target groups and the field of study, financial aid measures need to be complemented by other measures in order to foster enrolment.

\subsection{Preparatory Courses and Programs}

Preparatory courses and programs aim to even out previous or existing inequalities with regards to prospective students' previous education (can refer to, i.e., the quality of previous education, switch of the field of study, the language of instruction, academic ability, etc.). They target first-generation and non-traditional students, disadvantaged and students who do not have any experiences with academia and HE. The general purpose of these measures is to enable the students to prepare efficiently to continue their studies towards HE. The format in which these courses and programs take place can differ from university to university (see Table 4): intensive academic courses in areas students would like to pursue HE studies, general academic preparation (academic writing, critical thinking and study skills), auditing courses, introductory semesters, language courses enabling students to pursue studies in English (or other) language, but also general application process support and information. Completing the program enables students to apply for university in various fields of study but also to gain first-hand experience and insights into a HE program. Last but not least, such measures could also contribute to enhancing students' familiarity with a HE environment and help them overcome (academic and social) integration barriers at universities.

In Germany, prospective refugee students-who are treated like all international students-during their application and enrolment, receive special support in order to deal with their specific situation. Since the entrance criteria for the preparatory colleges include advanced knowledge of the German language, special classes prepare them for the entrance test in order to enrol in the preparatory courses. According to Berg (2018), these preparatory colleges and courses can be seen as important institutions for the internationalization of German HE and the support of prospective refugee students. 
Table 4 Selected examples of preparatory courses and programs

\begin{tabular}{|c|c|c|c|}
\hline HEI & $\begin{array}{l}\text { Type of measure and } \\
\text { components }\end{array}$ & Target group & Intended goal(s) \\
\hline $\begin{array}{l}\text { Leuphana University, } \\
\text { Germany }\end{array}$ & $\begin{array}{l}\text { A first semester as an } \\
\text { induction period }\end{array}$ & Mainstream students & $\begin{array}{l}\text { Familiarity with } \\
\text { academic life and } \\
\text { reduce drop-out }\end{array}$ \\
\hline $\begin{array}{l}\text { Technical University } \\
\text { of Munich, University } \\
\text { of Tuebingen and } \\
\text { Bielefeld, Germany }\end{array}$ & $\begin{array}{l}\text { Free German language } \\
\text { courses }\end{array}$ & Refugees & $\begin{array}{l}\text { Prepares students for } \\
\text { HE studies at German } \\
\text { universities }\end{array}$ \\
\hline $\begin{array}{l}\text { Central European } \\
\text { University, Budapest }\end{array}$ & $\begin{array}{l}\text { Preparatory, } \\
\text { non-degree language } \\
\text { and academic courses, } \\
\text { tutoring-OLIve, } \\
\text { Roma graduate } \\
\text { preparation }\end{array}$ & $\begin{array}{l}\text { Roma, refugees and } \\
\text { asylum-seekers }\end{array}$ & $\begin{array}{l}\text { Prepares students for } \\
\text { HE studies at } \\
\text { international } \\
\text { universities }\end{array}$ \\
\hline Brunel University, UK & $\begin{array}{l}\text { Preparatory monthly } \\
\text { sessions in key } \\
\text { subjects, guest } \\
\text { speakers and role } \\
\text { models-The urban } \\
\text { scholars programme }\end{array}$ & $\begin{array}{l}\text { Prospective talented } \\
\text { students from deprived } \\
\text { areas }\end{array}$ & $\begin{array}{l}\text { To increase } \\
\text { achievement and } \mathrm{HE} \\
\text { aspirations }\end{array}$ \\
\hline $\begin{array}{l}\text { University of Vienna, } \\
\text { Austria }\end{array}$ & $\begin{array}{l}\text { Free academic } \\
\text { courses-Open } \\
\text { learning initiative }\end{array}$ & $\begin{array}{l}\text { Individuals with } \\
\text { refugee or } \\
\text { asylum-seeking status }\end{array}$ & $\begin{array}{l}\text { Preparation for the } \\
\text { Austrian academic HE } \\
\text { system pursuing }\end{array}$ \\
\hline $\begin{array}{l}\text { Frankfurt University } \\
\text { of Applied Sciences, } \\
\text { Germany }\end{array}$ & $\begin{array}{l}\text { Intensive language } \\
\text { course, attending } \\
\text { modules over two } \\
\text { semesters-Welcome } \\
\text { year for refugees }\end{array}$ & Refugees & $\begin{array}{l}\text { Offering the } \\
\text { opportunity to take on } \\
\text { or continue a degree } \\
\text { course }\end{array}$ \\
\hline $\begin{array}{l}\text { Metropolia University } \\
\text { of Applied Sciences }\end{array}$ & $\begin{array}{l}\text { Training courses, } \\
\text { application processes } \\
\text { support }\end{array}$ & $\begin{array}{l}\text { Persons with an } \\
\text { immigrant background }\end{array}$ & $\begin{array}{l}\text { Increase the ability of } \\
\text { immigrant people to } \\
\text { enter HE }\end{array}$ \\
\hline
\end{tabular}

The Roma Graduate Preparation Program (formerly known as the Roma Access Programs) at Central European University (CEU) is an initiative providing preparatory courses for Roma students. The program aims to prepare Roma university graduates across Europe-through academic English, academic writing and tutoring in a field of choice - to compete for master's programs either at CEU or abroad. Since 2004, when it was founded, the program has enrolled 218 Roma students from all over Europe. Out of them, 215 graduated, and 141 (nearly 65\%) were accepted into a master's program at the end of their studies (Rostas 2017).

Pinheiro-Torres and Davies (2008) evaluate the Brunel University's Urban Scholars Programme, a 3-4 year intervention aimed at increasing achievement and $H E$ aspirations among talented students from lower socio-economic backgrounds and disadvantaged areas, aged 12-16. The paper discusses the emerging findings after 
the first 2 years of the program and suggests the biggest change occurs within scholars' confidence. Updated, self-reported data shows that program leavers had a HE orientation of $88 \%$ after 3-years attendance, and almost half of them received offers of places in universities, and $83 \%$ of them started HE studies. Looking at the same program, Casey et al. (2011) found that it "had some success in steering students toward greater ambition and an awareness of the rewards of higher education" ( $p$. 43 ), and that $90 \%$ of the students who participated and completed the programme either met or exceeded the school targets compared with $22 \%$ of the rest of the gifted and talented group who met or exceeded their school targets.

Walker (2010) investigates the academic performance of adults who entered the University of Glasgow via the Scottish Wider Access Programme (SWAP) between 1988-1993, including a pre-university summer school where non-traditional students (i.e., adults, with a socio-economic disadvantage) receive preparation and independent advice about opportunities to access HE. The findings show that there were few differences between the students who attended the summer school and those who did not-both dropped-out at largely the same rate. Recent self-reported data shows that, since the first pilot of SWAP in 1987, more than 32,000 adults have taken the SWAP route to return to study, and helped many adults realize their potential and given them the confidence to succeed in college or university. In general, preparatory courses and programs prove promising efficiency, however, this depends on their specific components.

\section{Conclusions}

Overall, this research found little publicly available studies and information about the actual outcomes of most measures. First of all, the identified studies cover a limited number of access measures available in Europe (i.e., none of the studies identified looked at the effectiveness of the widespread online platforms-most of them targeting refugees). Secondly, the existing studies do not provide a comprehensive geographical overview across Europe. With few exceptions, most of the identified research explores the context of the UK, Germany, France, Italy or Finland. This suggests that more evidence-based approaches will be necessary to effectively learn from these specific access measures.

The impact measurement is hampered by the impossibility of isolating the effects of such policies in order to attribute cause and effect, as well as by the difficulty of generalizing particular results. The current promising but limited amount of research in the European context shows that the most effective way to tackle unequal access to $\mathrm{HE}$ is the measures that combine financial assistance with measures that help to overcome non-financial obstacles. Success is also guaranteed by cooperation between governments, HEIs or other education providers, NGOs, public authorities (in fields like health or welfare that complement the interventions in education), families and/or private companies. Programs with a positive track record in terms of improving equity seem to be those combining financial support with non-financial aid offered 
to students (Salmi and Bassett 2014) as well as those empowering students, setting high academic expectations and helping students and parents believe in themselves and in their educational success (Usher 2015). These latter ones tend to be more intrusive and require frequent contact with the targeted individuals-e.g. academic support, mentoring programs.

Usher (2015) contends that making definitive statements about "what works" is hindered by the impossibility to generalize particular results (i.e., issues of transferability in different institutional settings) and the tendency to re-define the term "equity" when results become inconvenient (i.e., politically unwelcomed results). Similarly, Claeys-Kulik et al. (2019) argue that the collection and use of data on equity are often subject to controversial discussions, and perspectives vary according to cultural, political and legal contexts across Europe.

Lack of adequate, reliable and consistently collected data is often used as an excuse for the lack of action towards more equitable systems, but it also hinders the option of evidence-based policy-making or of measuring the impact of the initiatives already put into practice. Referring to specific measures targeting refugees, Streitwieser et al. (2019) argue that while sponsors described their plans for supporting refugees, they often do not share the amount of funding, the number of beneficiaries impacted, and other key data.

To conclude, this paper addressed a question about the relative effectiveness of various university-level access measures for underrepresented groups. The inference that can be made from this literature review is that all measures have a limited effect when implemented solely. More profound effects can be reached when the access measures are implemented in combination with each other, accounting also for the field of study and underrepresented group in focus.

The recommendations to policy-makers would include using, developing and ensuring prospective students' access to both financial and non-financial aid measures in their combination. The measures that have been already developed and validated at other, but similar context could be put in practice first. Development of new measures, their constant evaluation and extensive research on their effectiveness should be encouraged both by the HEIs themselves and national governments.

Acknowledgements The paper developed under the European Universities - Critical Futures project at Aarhus University, Denmark

\section{References}

Abbiati, G., Argentin, G., Barone, C., \& Schizzerotto, A. (2018). Information barriers and social stratification in higher education: evidence from a field experiment' The British Journal of Sociology, 69, 1248-1270.

Baumgartner, H. J. \& Steiner, V. (2006). Does More Generous Student Aid Increase Enrolment Rates into Higher Education? Evaluating the German Student Aid Reform of 2001. IZA Discussion Paper No. 2034. Available at SSRN: https://ssrn. com/abstract $=892831$. 
Berg, J. (2018). A new aspect of internationalisation? Specific challenges and support structures for refugees on their way to German higher education. In A. Curaj, L. Deca, \& R. Pricopie (Eds.), European higher education area: The impact of past and future policies, (pp. 219-235). Switzerland: Springer Link Open Access.

Bergen Communiqué. (2005). The European Higher Education Area - Achieving the Goals. Available online at: http://www.ehea.info/media.ehea.info/file/2005_Bergen/52/0/2005_Bergen_ Communique_english_580520.pdf.

Bucharest Communiqué. (2012). Making the most of our potential: Consolidating the European higher education area. Available online at: http://www.ehea.info/Uploads/(1)/Bucharest \%20Communique\%202012(2).pdf.

Casey, R., Smith, C. P., \& Koshy, V. (2011). Opportunities and Challenges of Working with Gifted and Talented Students in an Urban Context: A University-Based Intervention Program. Gifted Child Today, 34(1), 35-43.

Claeys-Kulik, A. L., Jorgensen, T. E., \& Stöber, H. (2019). Diversity, equity and inclusion in European higher education institutions: results from the INVITED project. European University Association: Brussels. Available online at: https://eua.eu/downloads/publications/web_diversity $\% 20$ equity $\% 20$ and $\% 20$ inclusion $\% 20$ in $\% 20$ european $\% 20$ higher\%20education $\% 20$ institutions. pdf.

Cowan, J. (1985). Effectiveness and efficiency in higher education. Higher Education, 14, 235-239.

Cullen, J. (2013). Guidance for inclusion practices and needs in European universities. STAY IN Consortium. European Commission.

Doyle, M., \& Griffin, M. (2012). Raised aspirations and attainment? A review of the impact of Aimhigher (2004-2011) on widening participation in higher education in England. London Review of Education, 10(1), 105-115.

Ehlert, M., Finger, C., Rusconi, A., \& Solga, H. (2017). Applying to college Do information deficits lower the likelihood of college-eligible students from less-privileged families to pursue their college intentions?: Evidence from a field experiment. Social Science Research, 67, 193-212.

European Commission/EACEA/Eurydice. (2018). The European Higher Education Area in 2018: Bologna Process Implementation Report. Luxembourg: Publications Office of the European Union. Available online at: https://eacea.ec.europa.eu/national-policies/eurydice/content/ european-higher-education-area-2018-bologna-process-implementation-report_en.

Fack, G., \& Grenet, J. (2015). Improving College Access and Success for Low-Income Students: Evidence from a Large Need-Based Grant Program. American Economic Journal: Applied Economics, 7(2), 1-34.

Geven, K. (2012). "Equity of what?" Understanding Policy for equity in higher education. MA thesis, Department of Public Policy, Central European University. Available online at: http:// www.etd.ceu.edu/2012/geven_koen.pdf.

Gumaelius, L., Almqvist, M., Árnadóttir, A., Axelsson, A., Conejero, J.A., García-Sabater, J.P., Klitgaard, L., Kozma, C., Maheut, J., Marin-Garcia, J., Mickos, H., Nilsson, P., Norén, A., PinhoLopes, M., Prenzel, M., Ray, J., Roxå, T., \& Voss, M. (2016). Outreach initiatives operated by universities for increasing interest in science and technology. European Journal of Engineering Education, 41(6), 589-622.

Haj, C. M., Geanta, I. M., \& Orr, D. (2018). A typology of admission systems across Europe and their impact on the equity of access, progression and completion in higher education. In A. Curaj, L. Matei, R. Pricopie, J. Salmi, \& P. Scott (Eds). European Higher Education Area: The Impact of Past and Future Policies, (pp. 171-187). Cham: Springer.

Hatt, S., Hannan, A., Baxter, A., \& Harrison, N. (2005). Opportunity knocks? The impact of bursary schemes on students from low-income backgrounds. Studies in Higher Education, 30(4), 373388.

Herbaut, E., \& Geven, K. M. (2019). What works to reduce inequalities in Higher Education? A systematic review of the (quasi-) experimental literature on outreach and financial aid. The World Bank. 
Lannert, J., \& Garaz, S. (2014). The Academic and Professional Trajectory of REF's Law and Humanities Scholarship Program Student-Beneficiaries. Roma Education Fund: Budapest. Available online at: https://www.romaeducationfund.org/wp-content/uploads/2019/05/a_tracer_ study_ref_2014.pdf.

Marginson, S. (2016). The worldwide trend to high participation higher education: dynamics of social stratification in inclusive systems. Higher Education, 72, 413-434.

McCaig, C., \& T. Bowers-Brown. (2007). Aimhigher: Achieving social justice? Paper presented at the British Educational Research Association Annual Conference, Institute of Education, University of London, 5-8 September, London. Available at: www.leeds.ac.uk/educol/documents/ 168534.htm.

Murray, J. (2009). The Wider Social Benefits of Higher Education: What do We Know about Them?. Australian Journal of Education, 53(3), 230-244.

Myers, C. B., Brown, D. E., \& Pavel, D. M. (2010). Increasing Access to Higher Education among Low-Income Students: The Washington State Achievers Program. Journal of Education for Students Placed at Risk, 15(4), 299-321.

Orr, D., Usher, A., Haj, C., Atherton, G., \& Geanta, I. (2017). Study on the impact of admission systems on higher education outcomes. Final report. Brussels: European Commission.

Pekkala-Kerr, S., Pekkarinen, T., Sarvimaki, M., and Uusitalo, R. (2015) 'Post-Secondary Education and Information on Labor Market Prospects: A Randomized Field Experiment' IZA Discussion Papers 9372, Institute for the Study of Labor (IZA).

Perna, L. W., Rowan-Kenyon H., Bell, A., Scott L. T., \& Li, C. (2008). A Typology of Federal and State Programs Designed to Promote College Enrollment. The Journal of Higher Education, 79(3), 243-267.

Pham, C., \& Keenan, T. (2011). Counseling and college matriculation: Does the availability of counseling affect college-going decisions among highly qualified first-generation college-bound high school graduates. Journal of Applied Economics and Business Research, 1(1), 12-24.

Pharris-Ciurej, N., Herting, J. R., \& Hirschman, C. (2012). The impact of the promise of scholarships and altering school structure on college plans, preparation, and enrollment' Social science research, 41(4), 920-935.

Pinheiro-Torres, C., \& Davies, C. (2008). Preliminary Findings of a Four Year Intervention Programme for Higher Ability Students. Paper presented at the British Educational Research Association Annual Conference, Heriot-Watt University, Edinburgh, 3-6 September 2008. Available online at: http://www.leeds.ac.uk/educol/documents/175306.pdf.

Prodan, A., Maxim, E., Manolescu, I., Arustei, C.C., \& Guta, A.L. (2015). Access to higher education: influences and possible implications. Procedia Economics and Finance 20, 535-543.

Roma Education Fund. (2015). The Role of The Roma Health Scholarship Program (RHSP) In The Academic and Professional Trajectory Of Its Beneficiaries. Available online at: http://old. romaeducationfund.org/sites/default/files/publications/rhsp_tracer_study_2015_1.pdf.

Rostas, I. (2017). Get Roma Education to Do Better: Identity and Leadership in Higher Education. Journal of the European Higher Education Area, 74, 1-17.

Salmi, J. (2018). Social Dimension within a Quality Oriented Higher Education System. In A. Curaj, L. Matei, R. Pricopie, J. Salmi, \& P. Scott (Eds.), European Higher Education Area: The Impact of Past and Future Policies, (pp. 141-154). Cham: Springer.

Salmi J., \& Bassett, R. M., (2014). The equity imperative in tertiary education: Promoting fairness and efficiency' International Review of Education, 60(3), 361-377.

Streitwieser, B., Loo, B., Ohorodnik, M., \& Jeong, J. (2019). Access for Refugees into Higher Education: A Review of Interventions in North America and Europe. Journal of Studies in International Education, 23(4), 473-496.

Tonks, D., \& Farr, M. (2003). Widening access and participation in UK higher education. International Journal of Educational Management, 17(1), 26-36.

Torgerson, C., Gascoine, L., Heaps, C., Menzies, V., \& Younger, K. (2014). Higher Education access: Evidence of effectiveness of university access strategies and approaches. Sutton Trust, $47-64$. 
Usher, A. \& Medow, J. (2010). Global Higher Education Rankings 2010 - Affordability and Accessibility in Comparative Perspective. Toronto: Higher Education Strategy Associates. Available online at: https://higheredstrategy.com/wp-content/uploads/2011/09/GHER2010_FINAL.pdf.

Usher A. (2015). Equity and the Social Dimension: An Overview. In A. Curaj, L. Matei, R. Pricopie, J. Salmi, \& P. Scott (Eds.), The European Higher Education Area. Between Critical Reflections and Future Policies, (pp. 433-447), Cham: Springer.

Walker, L. (2010). Predicting or guessing: the progress of Scottish Wider Access Programme (SWAP) students at the University of Glasgow. International Journal of Lifelong Education, 19(4), 342-356.

Wang, L. (2011). Social exclusion and inequality in higher education in China: A capability perspective. International Journal of Educational Development, 31(3), 277-286.

Wulz, J., Gasteiger, M., \& Ruland, J. (2018). The Role of Student Counselling for Widening Participation of Underrepresented Groups in Higher Education. In A. Curaj, L. Matei, R. Pricopie, J. Salmi, \& P. Scott (Eds.), European Higher Education Area: The Impact of Past and Future Policies, pp. 203-218. Cham: Springer.

Yerevan Communiqué. (2015). Available online at: http://www.ehea.info/media.ehea.info/file/ 2015_Yerevan/70/7/YerevanCommuniqueFinal_613707.pdf.

Younger, K., Gascoine, L., Menzies, V., \& Torgerson, C. (2019). A systematic review of evidence on the effectiveness of interventions and strategies for widening participation in higher education. Journal of Further and Higher Education, 43(6), 742-773.

Open Access This chapter is licensed under the terms of the Creative Commons Attribution 4.0 International License (http://creativecommons.org/licenses/by/4.0/), which permits use, sharing, adaptation, distribution and reproduction in any medium or format, as long as you give appropriate credit to the original author(s) and the source, provide a link to the Creative Commons license and indicate if changes were made.

The images or other third party material in this chapter are included in the chapter's Creative Commons license, unless indicated otherwise in a credit line to the material. If material is not included in the chapter's Creative Commons license and your intended use is not permitted by statutory regulation or exceeds the permitted use, you will need to obtain permission directly from the copyright holder.

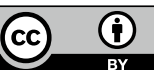

